\title{
Reproduction of Perna picta (Mollusca: Bivalvia) from the Atlantic coast of Morocco
}

\author{
M. S. Shafee \\ Section Halieutique, Institut Agronomique et Vétérinaire Hassan II, BP 6202, Rabat-Instituts, Rabat, Morocco
}

\begin{abstract}
The reproductive cycle of the mussel Perna picta (Born) on the Moroccan Atlantic coast near Rabat was studied by periodic observations of gonadal sections, dry tissue weights, biochemical composition and spatfall in a natural population. The sex ratio was 55:45 in favour of males; mussels attained sexual maturity at $22 \mathrm{~mm}$ shell length in both sexes. The general pattern of gametogenic activity of $P$. picta was comparable with that of Mytilus spp. reported from temperate regions. Gonad development began in October and the gonads were ripe in January or February. Spawnings and reconstitution of gametes took place several times between February and May, and the gonads entered the resting stage or showed reduced activity in summer (June to September). Recruitment occurred between May and September. As in Mytilus spp. from temperate regions, there was an inverse relationship between carbohydrate and protein in the storage and utilisation cycles of these 2 components. While carbohydrate reserves accumulated in the tissues during periods of gonadal inactivity (summer and autumn), protein was stored during periods of gonad development (winter). Energy values calculated per $\mathrm{g}$ ash free dry tissue weight fluctuated between 22.3 and $24.4 \mathrm{~kJ}$ and energy content ( $\mathrm{kJ}$ ind. ${ }^{-1}$ ) was maximal in winter and minimal in summer
\end{abstract}

\section{INTRODUCTION}

Warm-water mussels belonging to the genus Perna have attracted considerable research interest by virtue of their economic importance. According to Siddall (1980), only 3 living species are represented in this genus, each having a specific geographical distribution: $P$. viridis L., in Asian waters, $P$. canaliculus Martyn from the coasts of New Zealand and $P$. perna on both coasts of Africa and on the eastern coast of South America. Mussels of the genus Perna distributed around the Mediterranean coast of Africa are usually reported to be Perna perna L. (Lubet 1973, Zaouali 1973, Abda-Boudjema \& Mouëza 1981, AbdaBoudjema et al. 1984), thereby agreeing with the nomenclature proposed by Siddall (1980). On the other hand, Nordsieck (1969) and Buccheri \& Palisano (1976) remarked that these mussels on Mediterranean and North African coasts present certain ecomorphological differences from $P$. perna and consequently they considered these as a new species, namely Perna picta (Born). This species name has been widely used in recent catalogues of Mediterranean molluscs (Piani 1980, Fisher et al. 1987).

Observations using histological sections of gonads on gametogenic and breeding activities of mussels of the genus Perna from tropical regions are well documented (Lunetta 1969, Virabhadra Rao et al. 1975, Walter 1982). However, to date, reproductive studies of these mussels from warm temperate regions deal only with indirect observations such as the appearance of larvae in the plankton (Booth 1977), settlement of spat (Greenway 1969a, b, 1975, Zaouali 1973, Berry 1978, AbdaBoudjema \& Mouëza 1981) and body condition index in relation to reproductive activities (Hickman \& Illingworth 1980). Interpretation of these findings is difficult because these observations lack the precision possible from study of gonad histology. However, perusal of these data suggests that mussels Perna spp. in tropical or subtropical waters show prolonged activities of reproduction and spawning practically throughout the year while spawning tends to become seasonal at higher latitudes. The present work was undertaken in order to understand the reproductive biology of a warm temperate population of $P$. picta which is found along the Moroccan Atlantic and Mediterranean coasts and forms an important fishery in Morocco. Both indirect observations, such as spatfall and storage and utilisation of body reserves, and direct observation of gametogenesis using histological sections of the gonads were taken into consideration during the study to assess the reproductive cycle of $P$. picta in Temara (Rabat). 


\section{MATERIALS AND METHODS}

Sampling site. Samples were taken from a mussel bed of Perna picta (Born) at Temara situated on the Moroccan Atlantic coast (Fig. 1), $15 \mathrm{~km}$ south of Rabat. Geomorphological characters of this site were described by Guilcher \& Joly (1954) and Gantes (1967). The sampling station at Temara is bordered by quaternary calcareous rocks. The population of $P$. picta occurring in the upper infralittoral zone was investigated during this study. This zone is submerged by seawater most of the time and is exposed only during low spring tides. A rich flora and fauna occupy this zone. Another species of mussel, Mytilus galloprovincialis, occurs with $P$. perna and flora such as cystosiera, coralline algae, and rhodophytes occur in dense quantity in the mussel bed. Gastropods, ophiuroids, polychaetes, amphipods, cirripedes, decapods and isopods are also well represented in this zone.

Environmental parameters. Beginning in February 1983, temperature, salinity and chlorophyll a content of the seawater in the vicinity of the mussel population was measured at regular weekly intervals. Temperature was measured using a thermometer and salinity by silver nitrate titrations. Chlorophyll a was measured by filtering water samples through a Whatman GF/C glass fibre filter and dissolving the plant pigments in $90 \%$ acetone. Extinction values of this solution were measured at different wavelengths as recommended by SCOR/UNESCO equations.

Mussel sampling. Mussel samples were collected at fortnightly intervals from 1 February 1983 to 6 January
1984, during low spring tides from the upper level of the infralittoral zone where the mussel population was exposed to the air for an average $2 \mathrm{~h} \mathrm{~d}^{-1}$. During every sampling period 10 to 15 samples were collected at random using a $150 \mathrm{~cm}^{2}$ quadrat. The contents of each sample were sorted through $2 \mathrm{~mm}$ mesh sieves to collect all mussels measuring more than $3 \mathrm{~mm}$ shell length. $P$. perna was easily identified using characters previously described for its genus by Lubet (1973) and Siddall (1980). The number of spat measuring less than $9 \mathrm{~mm}$ was recorded seperately for each quadrat and sampling period.

Examination of gonad development. Approximately 100 mussels of 15 to $80 \mathrm{~mm}$ shell length were taken at random from different quadrats. Each mussel was measured along its maximum anterior-posterior axis (length), opened and the reproductive condition observed macroscopically. This observation included: mantle and mesosoma colour, appearance of follicles in the mantle, texture of the mantle and the extent to which the mantle tissue was invaded by the genital tissue.

A further 10 to 20 individuals ranging in shell length from 50 to $70 \mathrm{~mm}$ were used for microscopical examination of gonads. The central portion of the right mantle lobe of each mussel was removed and fixed in Bouin's fluid for 1 to $2 \mathrm{wk}$. Tissues were embedded in wax (melting point $=58^{\circ} \mathrm{C}$ ) after dehydration in alcohol. Sections of 5 to $7 \mu \mathrm{m}$ were prepared and stained with Masson's Trichrome solutions (Martoja \& Martoja 1967). Stained sections were then classified into different gametogenic stages as described by Wilson \& Seed (1974) and Kennedy (1977). A gonad index

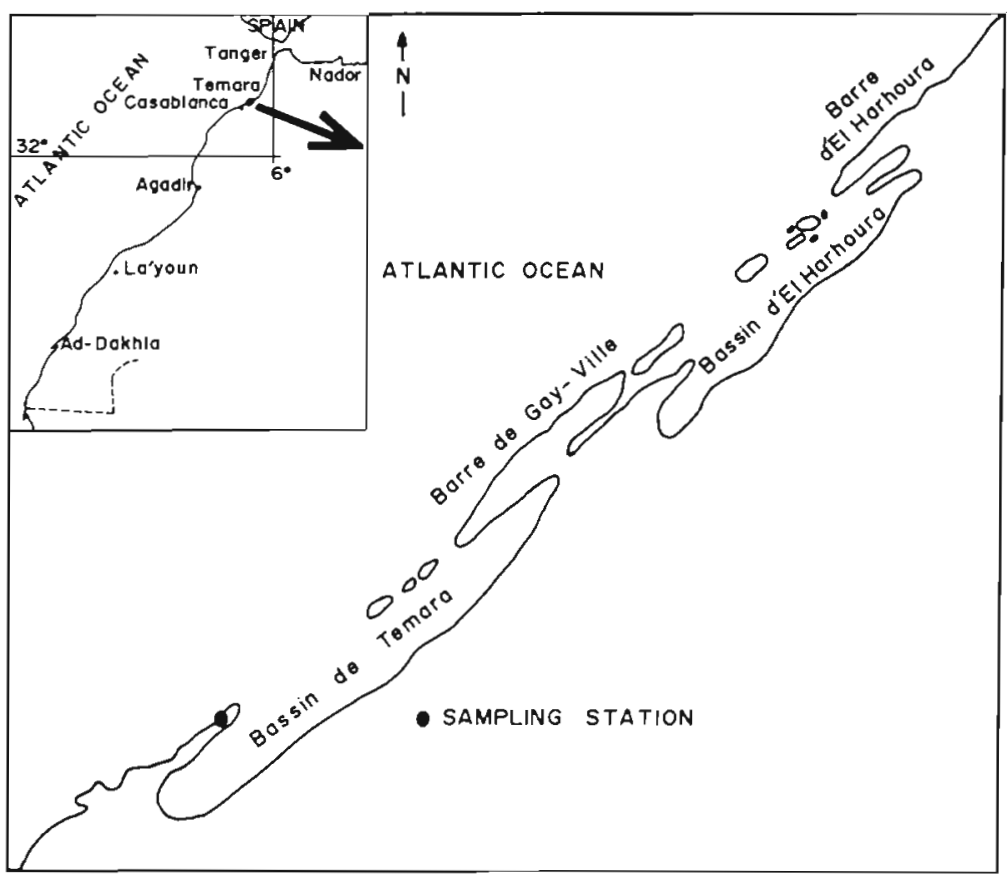

Fig. 1. Northwest coast of Morocco showing study site at Temara 
was calculated for each sample by ranking the different gametogenic stages as follows:

$\begin{array}{ll}\text { Stage 0 (resting stage) } & : 0 \\ \text { Stage } 1 \text { (early development) } & : 1 \\ \text { Stage 2 (later development) } & : 2 \\ \text { Stage 3A (morphologically ripe) } & : 3 \\ \text { Stage 3B (spawning) } & : 2 \\ \text { Stage 3C (redeveloping or redeveloped) } & : 2 \\ \text { Stage 3D (recently spent) } & : 1\end{array}$

For each sample, the number of mussels at each stage was multiplied by the numerical score of that stage. The products were summed and the result divided by the total number of mussels in the sample. Gametogenic development was indicated by an increase in the index while a decrease indicated that spawning was occurring. When 2 or more stages occurred simultaneously in a section, the stage recorded was based upon the condition of the majority of the section.

Tissue weight measurements. Two sets of 25 mussels of sizes ranging from 30 to $80 \mathrm{~mm}$ were taken from the samples collected. One set of mussels was analysed to derive the shell length vs whole dry body weight relationship, and the other set for the shell length vs dry mantle weight relationship. The tissues were dried at $60^{\circ} \mathrm{C}$ for $48 \mathrm{~h}$. The following functional regression equation (Ricker 1973) was used to relate shell lengths to dry flesh weights for each sampling period:

$$
\operatorname{Ln} W=\ln a+b \ln \mathrm{L}
$$

where $W=$ dry weight of the flesh $(g)$ (either whole body without shell or mantle tissue); $L=$ shell length $(\mathrm{mm})$. From these regression equations, dry flesh weight of a standard mussel measuring $60 \mathrm{~mm}$ shell length was calculated for each sampling period.

Biochemical analyses. Dried tissues of the whole mussel without shell were combined and grouped in a mortar for further biochemical analyses. Protein was estimated by the Kjeldahl method, lipid was extracted in petroleum ether for $24 \mathrm{~h}$ in a soxhlet apparatus and ash determined by burning the tissue at $450^{\circ} \mathrm{C}$ for $12 \mathrm{~h}$. Carbohydrate was assumed to be the difference of the sum of the above 3 fractions from $100 \%$. Energy value of the dry flesh was calculated using the conversion factors of its biochemical components: $17.2 \mathrm{~kJ} \mathrm{~g}^{-1}$ for carbohydrate, $23.6 \mathrm{~kJ} \mathrm{~g}^{-1}$ for protein (Brody 1945), 36.0 $\mathrm{kJ} \mathrm{g}^{-1}$ for lipid (Beukema \& De Bruin 1979).

\section{RESULTS}

\section{Environmental parameters}

Salinity of the coastal waters in Temara varied between $33.2 \%$ and $35.93 \%$ during the period of this study. Lower values occurred during the rainy season (October to February) and higher values during the dry season (March to September). Water temperature showed considerable seasonal variation (Fig. 2) with extreme values of $23^{\circ} \mathrm{C}$ in summer (late June to September) and $14^{\circ} \mathrm{C}$ in winter. Seasonal variation in chlorophyll $a$ at Temara resembled that in other temperate regions (Fig. 3) with spring ( $3.5 \mathrm{mg} \mathrm{m}^{-3}$ ) and autumn $\left(2.12 \mathrm{mg} \mathrm{m}^{-3}\right)$ peaks and lowest values in winter $\left(0.12\right.$ to $\left.0.25 \mathrm{mg} \mathrm{m}^{-3}\right)$. Chlorophyll a content varied between 0.75 and $1.25 \mathrm{mg} \mathrm{m}^{-3}$ during summer.

\section{Recruitment}

Seasonal variation in the mean number of spat (2 to $9 \mathrm{~mm}$ shell length) collected during each sampling period is shown in Fig. 4. Though recruitment was continuous, peak periods occurred during spring (May and June). The density of spat per $0.150 \mathrm{~m}^{2}$ decreased during summer to reach low values in winter.

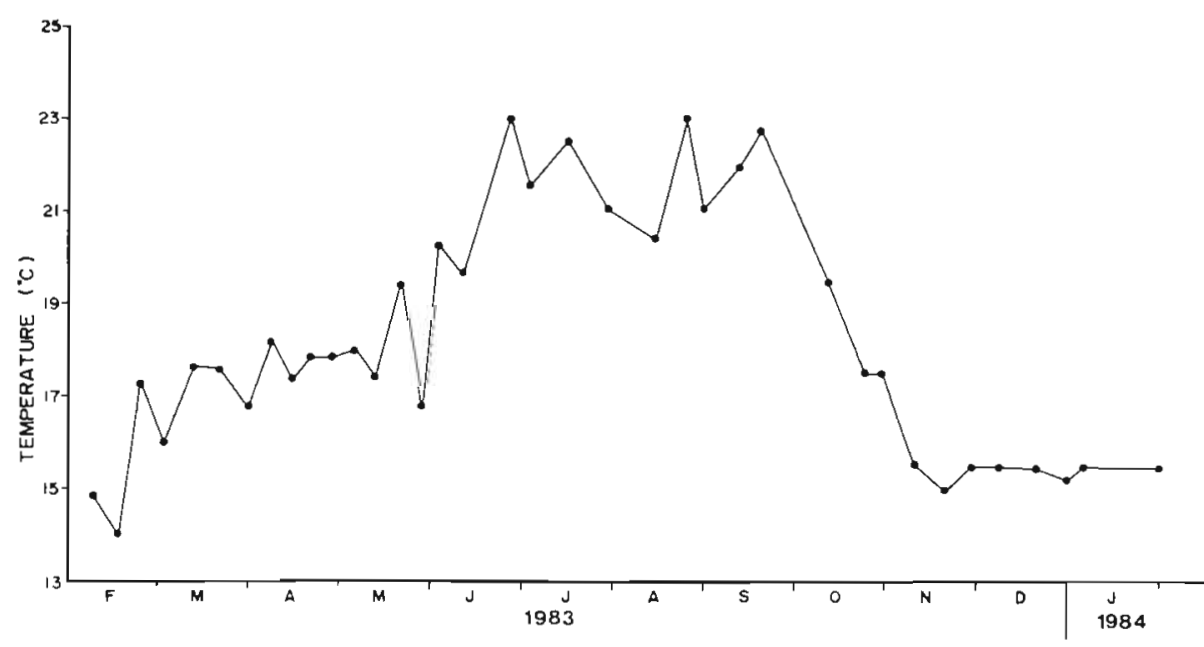

Fig. 2. Seasonal variation in seawater temperature at Temara 


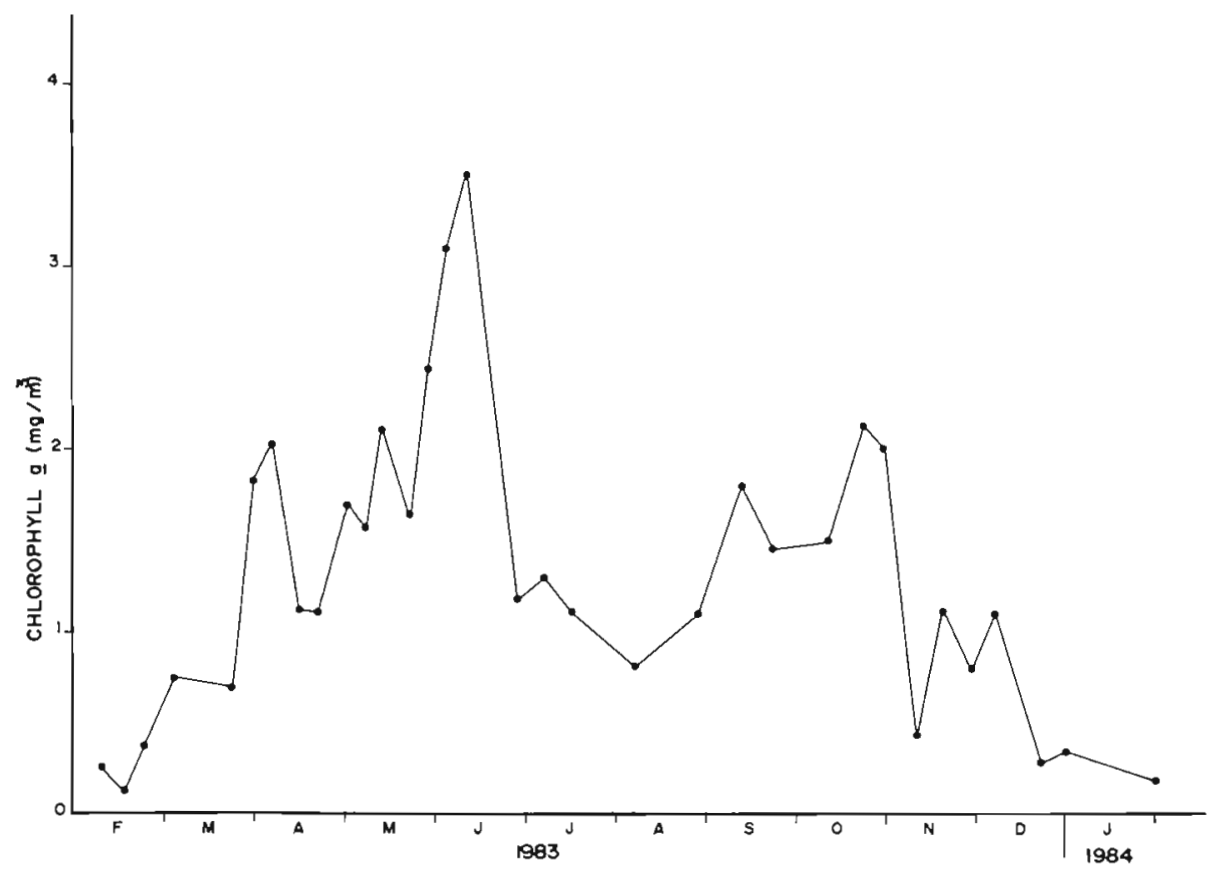

Fig. 3. Seasonal variation in chlorophyll a content of seawater at Temara

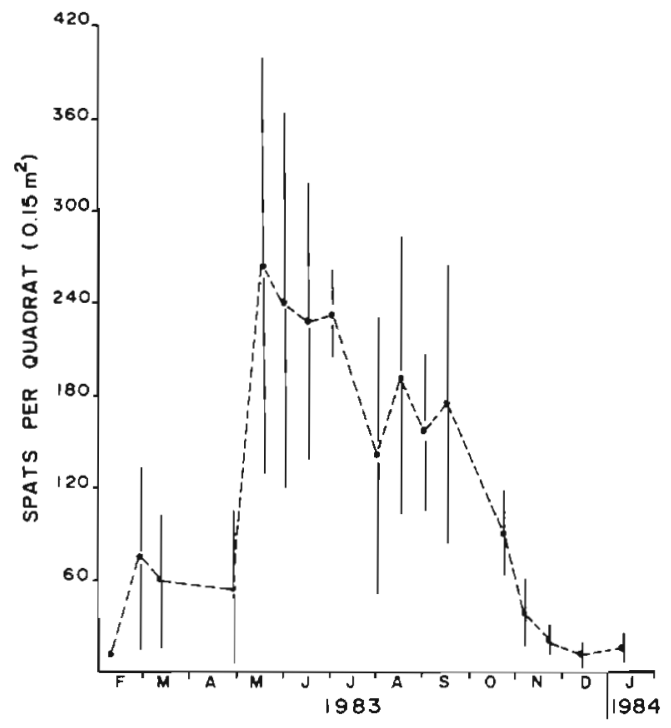

Fig. 4. Perna picta. Seasonal variation in the density of spats collected from the mussel population at Temara. Vertical lines indicate standard deviations from means

\section{Macroscopical examination of gonads}

Visual observations of opened mussels in the shell showed that follicular development occurred in the mantle tissue during gametogenic activity. When the gonads were ripe they occupied virtually the whole of the mantle tissues; the mantle was white in males and red in females. After spawning, the mantle was filled with white or cream-yellow liquid and the sex could not be determined by visual observations. Macroscopically it was difficult to differentiate spent stages from early developmental stages of the gonad. The mantles of mussels during both these periods were approximately the same colour (white or creamyellow). During slightly more advanced stages of gametogenesis mantles of females were often white with red patches. Sex differences in terms of mantle colour were evident from late December to early March when the gonads were in an advanced stage of development. Visual observations of gonads made during this period showed that Perna picta could become mature at $22 \mathrm{~mm}$ length. Both males and females of this size had pigmented mantles with gonad proliferation. Eight sets of mussels, with 100 mussels in each set, observed visually during this period showed a sex ratio of $54.5 \%$ males to $45.5 \%$ females. The results of a $5 \times 2$ contingency table test for the above sets of data were: $\chi^{2}=0.78, p=0.94$, $\mathrm{df}=7$.

\section{Microscopical examination of gonads}

Different gametogenic stages observed during the period of study, and illustrated in Figs. 5 and 6, can be explained as follows:

Stage 0: Resting stage. In this stage, sex is indeterminate and no follicles can be observed in the mantle tissue. Genital canals are obscured by densely packed connective tissue. 
Stage 1: Early development. First signs of gametogenesis become apparent. Small groups of germinal cells are scattered in the mantle. Spermatogonia and oogonia line the follicle wall, but sex determination is sometimes difficult during the early phases of this stage.

Stage 2: Later development. The follicles in both males and females occupy a large part of the mantle. In the male follicles, there is a wide centripetal band of spermatogonia, spermatocytes and spermatids, with some spermatozoa scattered among the larger cells. In the female, oocytes have begun to accumulate yolk and have grown considerably. Young oocytes are still attached to the follicular wall by a slender stalk of cytoplasm, but some mature oocytes are free in the lumen.

Stage 3A: Morphologically ripe. The mantle is now filled with follicles occupying almost the entire area. In the male the follicles are packed with spermatozoa arranged in lamellae converging towards the centre of the lumen. A few residual spermatocytes and spermatids may still be present. In the female the majority of the oocytes have reached their maximum size and lie packed tightly together in the follicles. The pressure within these follicles compresses the oocytes into polygonal shapes.

Stage 3B: Spawning. A large number of almost ripe ovocytes is still present in the large expanded follicles, or dense bands of ripe spermatozoa surround a partially empty lumen but their arrangement in lamellae has now disappeared.

Stage 3C: Redeveloping or redeveloped. Soon after Stage 3B, a new phase of renewed gametogenesis may occur. There is a rapid proliferation and growth of oocytes and a densely staining band of spermatids gives rise to new lamellae of spermatozoa. This stage can be confused with Stage 2, but when full redevelopment has occurred (the equivalent of Stage $3 \mathrm{~A}$ ) the packed follicles do not occupy all the available mantle area. Thus more connective tissue is evident than before initial spawning (3B).

Stage 3D: Recently spent. Follicles collapse and degenerate. Amoebocytes attack unspawned gametes, often resulting in the lumen of follicles becoming filled with a mass of cellular debris. The mussel returns to the resting stage.
A detailed analysis of the gametogenic cycle is represented as the percentage distribution of different stages in Table 1 . When sampling began on 1 February 1983, all mussels had ripe gonads. Though the major spawning occurred in early spring, several partial spawnings followed by redevelopment of gametes took place between February and May. Between June and September, the number of mussels in the spent or resting stages increased. However, during this period, certain gonads, although showing signs of redevelopment, never attained the fully ripe stage (3A). Mature gametes in some gonads were slowly reabsorbed by phagocytic cells. Gonad development began in autumn and more than $50 \%$ of the population had ripe gonads by early January 1984. The gonad index (Table 1, Fig. 7) summarizes the decline from the morphologically ripe condition in winter to an inactive period from June to September and the recommencement of gametogenesis in autumn.

\section{Dry tissue weight}

Regression equations relating dry body weight/ length and dry mantle weight/length were calculated for every sampling period. By utilising these regression equations, dry body weight and mantle weight of a standard mussel measuring $60 \mathrm{~mm}$ in shell length were calculated for every sampling period; results are presented in Fig. 7. Dry body weight was high in autumn and winter but declined immediately after spawning in spring. During late summer dry weight began to increase again reaching maximum value in autumn. Seasonal changes in mantle weight followed more or less the seasonal changes in gonad index values (Fig. 7). Maximum mantle weight was observed in winter before spawning while lowest values were recorded in spring and summer following spawning.

\section{Biochemical composition}

The percentages of protein, carbohydrate, lipid and ash in dry tissue are presented in Table 2 , which also gives calculated energetic values for $1 \mathrm{~g}$ ash free dry tissue weight (AFDW). Protein and carbohydrate values showed marked seasonal variation and there is a clear inverse relationship between these 2 components. The protein fraction decreased from its maximal value (61 to $66 \%$ ) observed during the pre-spawning and spawning periods (December to May) to a lower value (51 to $60 \%$ ) during the remaining period (June to November). By contrast, the carbohydrate fraction attained its minimal value when the gonads were ripe in winter (9 to $12 \%$ ), started to increase after spawning 


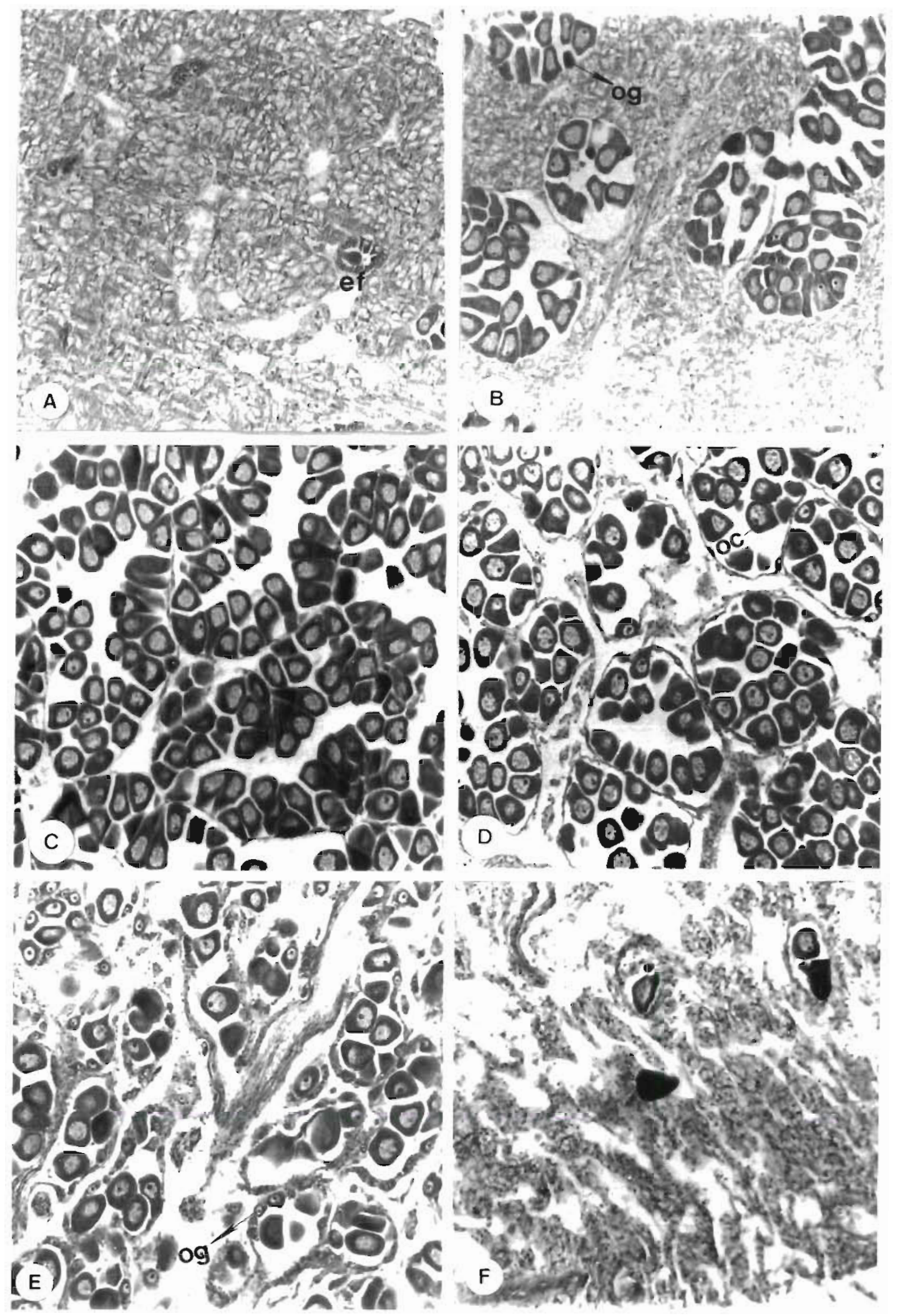

Fig 5 Perna prcta Different gametogenic stages observed in females at Temara (A) Stage 1, early development; (B) Stage 2, developing, (C) Stage 3A, ripe, (D) Stage 3B, spawning, (E) Stage 3C. redevelopment, (F) Stage 3D, spent. ef: early follicle; oc: 

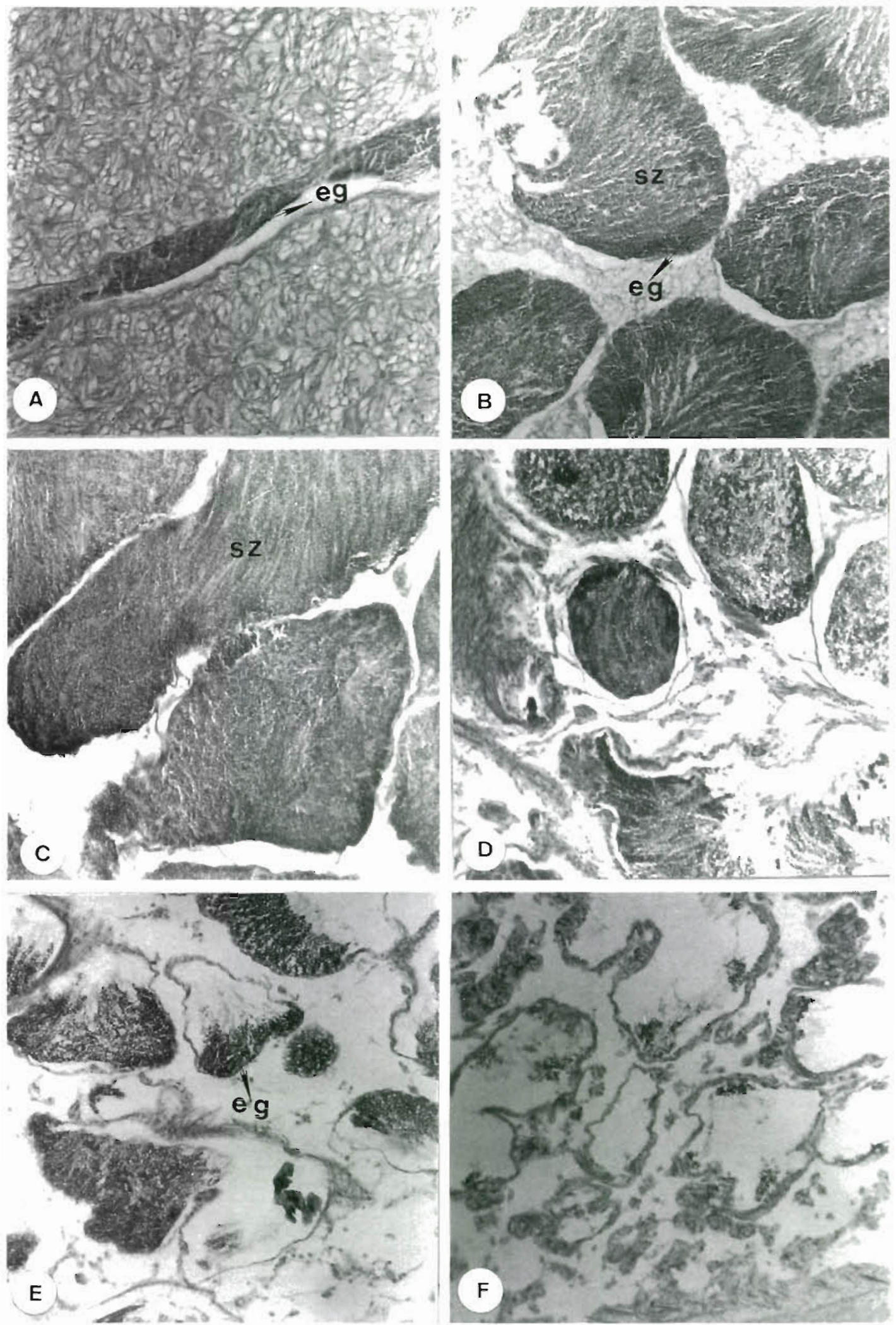

Fig. 6. Perna picta. Different gametogenic stages observed in males at Temara (A) Stage 1, early development; (B) Stage 2, developing; (C) Stage 3A, ripe; (D) Stage 3B, spawning, (E) Stage 3C, redevelopment, (F) Stage 3D, spent. eg early gametogenesis; sz spermatozoa 
Table 1. Perna picta. Distribution of the stages $(\%)$ of gonad development in samples from Temara, Rabat, Morocco (N: no. of mussels in sample)

\begin{tabular}{|c|c|c|c|c|c|c|c|c|c|c|}
\hline \multirow[t]{2}{*}{ Date } & & \multicolumn{7}{|c|}{ Stage } & \multirow[t]{2}{*}{$N$} & \multirow{2}{*}{$\begin{array}{l}\text { Gonad } \\
\text { index }\end{array}$} \\
\hline & & 0 & 1 & 2 & $3 \mathrm{~A}$ & $3 B$ & $3 \mathrm{C}$ & $3 D$ & & \\
\hline 1 Feb & 1983 & - & - & - & 100 & - & - & - & 20 & 3 \\
\hline 15 Feb & 1983 & - & - & - & 56 & 38 & 6 & -- & 16 & 2,5 \\
\hline $2 \mathrm{Mar}$ & 1983 & - & - & - & 100 & - & - & - & 10 & 3 \\
\hline $30 \mathrm{Mar}$ & 1983 & - & - & - & - & 36 & 50 & 14 & 14 & 1,9 \\
\hline $15 \mathrm{Apr}$ & 1983 & - & - & - & 20 & 60 & & 20 & 20 & 2,0 \\
\hline $29 \mathrm{Apr}$ & 1983 & - & - & - & - & 30 & 60 & 10 & 20 & 1,9 \\
\hline 12 May & 1983 & - & - & - & 9 & 36 & 27 & 28 & 11 & 1.8 \\
\hline $26 \mathrm{May}$ & 1983 & - & - & - & - & 40 & 10 & 50 & 20 & 1.5 \\
\hline 9 Jun & 1983 & 30 & - & - & - & - & 30 & 40 & 10 & 1,0 \\
\hline $24 \mathrm{Jul}$ & 1983 & 60 & - & - & - & - & 20 & 20 & 20 & 0,6 \\
\hline 7 Aug & 1983 & 40 & - & - & - & - & 20 & 40 & 10 & 0,6 \\
\hline $20 \mathrm{Aug}$ & 1983 & 40 & - & - & - & - & - & 60 & 10 & 0,6 \\
\hline 8 Sep & 1983 & 30 & 10 & - & - & - & - & 60 & 20 & $0, \hat{6}$ \\
\hline 23 Sep & 1983 & 10 & 20 & 10 & - & - & - & 60 & 20 & 0,7 \\
\hline $8 \mathrm{Oct}$ & 1983 & 20 & 40 & 20 & - & - & - & 20 & 20 & 1,0 \\
\hline 23 Oct & 1983 & 20 & 50 & 70 & - & - & - & - & 10 & 1,1 \\
\hline 7 Nov & 1983 & 9 & 27 & 64 & - & - & - & - & 11 & 1,6 \\
\hline $3 \mathrm{Dec}$ & 1983 & - & 18 & 36 & 46 & - & - & - & 11 & 2,3 \\
\hline $6 \mathrm{Jan}$ & 1984 & - & - & 47 & 53 & - & - & - & 15 & 2,5 \\
\hline
\end{tabular}

(15 to $22 \%$ ), and attained maximal values during periods of gonadal inactivity (up to $31 \%$ ). The percentages of lipid and of ash varied between 5 and $10 \%$ and between 10 and $18 \%$ respectively during the period of study, and both these components showed higher values just before the spawning period in winter.

Seasonal changes in the protein weight (Fig. 8) of a standard mussel followed very closely that for dry body weight. Protein weight was highest in winter, decreased gradually during spring (spawning periods) and attained its lowest values during summer. Protein reserves started

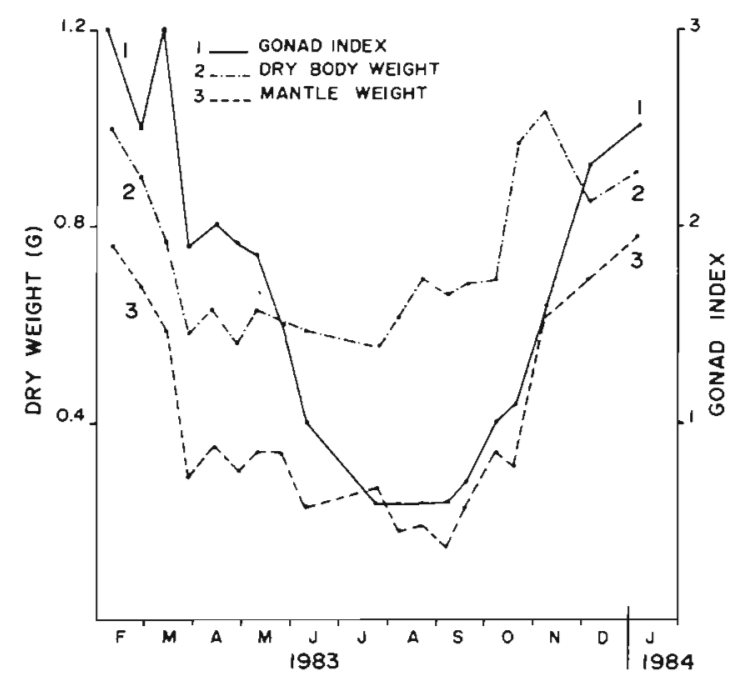

Fig. 7. Perna picta. Seasonal changes in the values of gonad index and dry tissue weights to accumulate in the tissues during autumn and attained their maximum values in winter. After depletion during the spawning periods (spring), lipid started to accumulate, a little earlier than protein, increasing gradually over the summer to its peak value in winter (Fig. 8). Carbohydrate accumulated in the tissues in summer soon after spawning and reached its maximum value in autumn just before the onset of gametogenesis. Depletion of carbohydrate occurred following the development of gametes, and reached a lower value during the pre-spawning and spawning periods (Fig. 8).

Calculated energy values for $1 \mathrm{~g}$ ash free dry tissue weight fluctuated between 22.3 and $24.4 \mathrm{~kJ} \mathrm{~g}^{-1}$ AFDW (Table 2). Lower values were noted in summer and higher values in winter. Seasonal changes in total energy content of a standard mussel (Fig. 8) showed the same seasonal trend as that of dry body weight.

\section{DISCUSSION}

Seasonal activities of reproduction in Perna picta from the Moroccan Atlantic coast in Temara (Rabat) may be summarized as follows:

(1) A period of gonadal inactivity in summer and autumn when reserves in the form of carbohydrates and lipids may accumulate in the tissues. Late spawning may occur in summer and gametogenesis may start slowly in autumn.

(2) A period of rapid gonad proliferation in winter at the expense of stored carbohydrate reserves. Protein and lipid contents of the tissue increase. 
Table 2. Perna picta. Biochemical components of specimens from Temara, Rabat, Morocco, expressed as percentages of dry tissue weight

\begin{tabular}{|c|c|c|c|c|c|c|}
\hline Date & & Protein & Lipid & Carbohydrate & Ash & $\begin{array}{c}\text { Calculated energy } \\
\text { content }\left(\mathrm{kJ} \mathrm{g}^{-1} \text { AFDW }\right)\end{array}$ \\
\hline $1 \mathrm{Feb}$ & 1983 & 64.01 & 7.93 & 10.70 & 17.36 & 23.98 \\
\hline $15 \mathrm{Feb}$ & 1983 & 64.37 & 7.73 & 10.30 & 17.60 & 23.98 \\
\hline $2 \mathrm{Mar}$ & 1983 & 66.14 & 9.78 & 8.64 & 15.44 & 24.40 \\
\hline $30 \mathrm{Mar}$ & 1983 & 66.38 & 4.55 & 15.73 & 13.34 & 23.11 \\
\hline $15 \mathrm{Apr}$ & 1983 & 65.16 & 5.60 & 15.59 & 13.65 & 23.27 \\
\hline 29 Apr & 1983 & 62.37 & 5.96 & 15.74 & 15.93 & 23.30 \\
\hline $12 \mathrm{May}$ & 1983 & 64.10 & 5.55 & 17.44 & 12.91 & 23.13 \\
\hline $26 \mathrm{May}$ & 1983 & 60.59 & 5.71 & 22.41 & 11.29 & 22.80 \\
\hline 9 Jun & 1983 & 59.22 & 5.33 & 24.53 & 10.92 & 22.60 \\
\hline $24 \mathrm{Jul}$ & 1983 & 59.61 & 7.18 & 21.58 & 11.63 & 23.06 \\
\hline 7 Aug & 1983 & 58.08 & 8.43 & 23.11 & 10.38 & 23.13 \\
\hline 20 Aug & 1983 & 51.34 & 6.43 & 30.70 & 11.53 & 22.29 \\
\hline 8 Sep & 1983 & 60.81 & 6.26 & 20.26 & 12.67 & 23.01 \\
\hline 23 Sep & 1983 & 58.33 & 6.14 & 23.60 & 11.93 & 22.76 \\
\hline 8 Oct & 1983 & 57.56 & 6.04 & 24.27 & 12.13 & 22.74 \\
\hline 23 Oct & 1983 & 58.55 & 6.00 & 23.65 & 11.80 & 22.74 \\
\hline 7 Nov & 1983 & 59.80 & 6.78 & 22.75 & 10.67 & 22.92 \\
\hline $3 \mathrm{Dec}$ & 1983 & 63.41 & 7.58 & 14.52 & 14.49 & 23.63 \\
\hline 6 Jan & 1984 & 65.23 & 7.71 & 11.86 & 15.20 & 23.85 \\
\hline
\end{tabular}
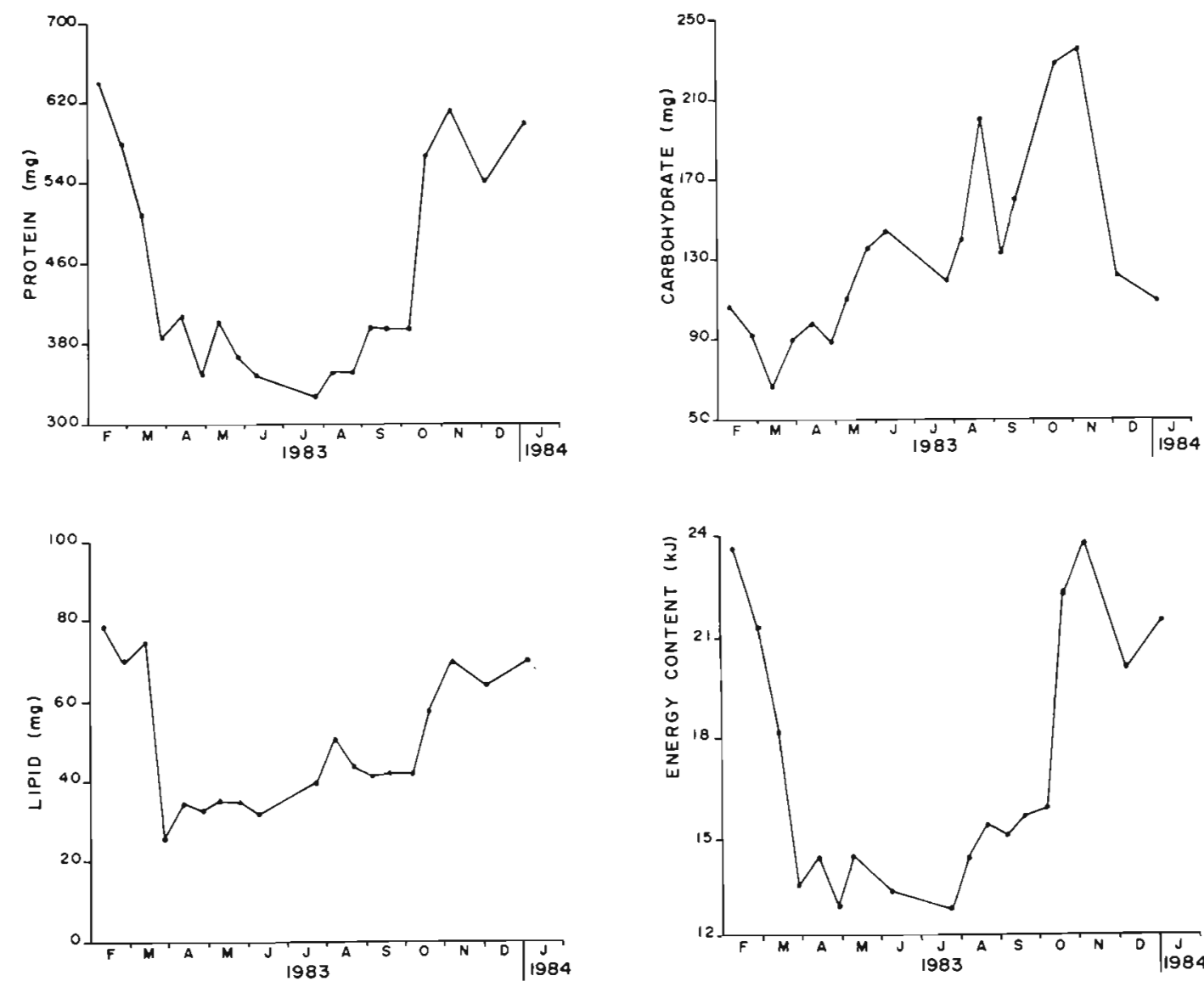

Fig. 8. Perna picta. Seasonal changes in biochemical composition of dried body tissue of standard mussel (measuring $60 \mathrm{~mm}$ in shell length) 
(3) A period of spawning in spring when both emission and rapid redevelopment of gametes may take place simultaneously. Tissue shows minimal values in its protein reserves.

The annual cycle of reproduction in Perna picta thus broadly corresponds to that of Mytilus spp. from temperate waters (Seed 1975, 1976, Kennedy 1977) where most of the mussels are winter-spring breeders. Though its reproductive behaviour is similar to that of Perna canaliculus from temperate regions of the southern hemisphere in New Zealand (Greenway 1969a, b, Kennedy 1977), it differs from other representatives of this genus ( $P$. perna and $P$. viridis) in tropical or subtropical regions where mussels may be ripe throughout much of the year (Lunetta 1969, Lubet 1981, Lee 1986). While in warm waters the mussels may show opportunistic behaviour of spawning in relation to sudden climatic changes, such as in water temperature, rain, or monsoon (Lubet 1981), in temperate regions gonad development and spawning become essentially seasonal, thereby showing conservative behaviour.

Gametogenesis and gonad proliferation in Perna picta start in autumn when water temperature begins to fall. Gonads become morphologically ripe during the cooler months when the water temperature decreases to $15^{\circ} \mathrm{C}$. Practically all reproductive activities of spawning cease soon after spring when the water temperature rises above $18^{\circ} \mathrm{C}$. In summer, some unspawned but ripe gametes may still remain tightly packed in certain follicles of some gonads. Later on (in late summer and in early autumn) these follicles are found to degenerate and resorption of gametes occurs by phagocytosis. Though reduction in the number of gametes in these unspawned follicles (equivalent to Stage 3B) was never noticed in summer, it is difficult to conclude whether summer spawning occurs in $P$. picta or not. After the spring spawning, mussels did not show completely ripe gonads (equivalent to Stage $3 \mathrm{~A}$ ) until the following winter. However, a major part of the population can be found in the resting stage during the warmer months with temperatures between 20 and $23^{\circ} \mathrm{C}$.

The recruitment period (May to September) reported for Perna picta during this study is in close agreement with the observations of Abda-Boudjema \& Mouëza (1981) on the Algerian coast. In contrast, Zaouali (1973) reported continuous recruitment throughout the year in Tunisia with peak spatfall in autumn. Observation of breeding activities based only on the presence or absence of spat settling within the population may not indicate precisely the exact spawning periods of mussels. Primary settlement of plantigrades may take place on a temporary substrate from which they may later invade the established population (Seed 1976). Therefore, the breeding season reported for $P$. picta from the
North African coast based on observations of spatfall alone must be considered with caution.

In addition to its reproductive cycle, Perna picta also closely resembles mussels of the genus Mytilus from temperate regions in the way it accumulates and utilises energy reserves. Due to a sufficient food supply in the form of phytoplankton during spring and autumn (Fig. 3), P. picta accumulates carbohydrate reserve starting from May-June up to October-November and utilises it in winter when available food is insufficient to meet gonadal activities. Protein and lipid are built up along with the gametes in late autumn and winter. Energy content of a standard mussel, therefore, shows higher values during these periods due to its higher protein content.

Acknowledgements. Some of my students, particularly Miss Mina Guerimej, Miss Zineb Maghza, Mr Mohammed Benbrahim, Mr Mohamed Moussali and Mr Williams James participated in the work reported here while completing their research training courses. I hope and trust that they have benefited from this work as much as they have contributed to the present study. I thankfully acknowledge the award of a Research Grant from the International Foundation for Science, Stockholm, Sweden (Contract No. A/707). Dr R. Seed (University College of North Wales) commented upon this paper and offered valuable suggestions for the presentation.

\section{LITERATURE CITED}

Abda-Boudjema, Y., Altes, J., Mouëza, M. (1984). Croissance comparée de deux espèces de moules Mytilus galloprovincialis Lmk et Perna perna L. dans une moulière naturelle de la baie d'Alger. Haliotis 14: 33-38

Abda-Boudjema, Y., Mouëza, M. (1981). Structure des populations dune moulière naturelle en baie d'Alger. Acta Oecologica, Oecol. gen. 2 (2): 183-194

Berry, P. F. (1978). Reproduction, growth and production in the mussel, Perna perna (Linnaeus) on the east coast of South Africa. S. Afr Ass. Mar. Ecol. Res., Oceanogr. Res. Inst. Rep. 48: 1-28

Beukema, J. J., De Bruin, W. (1979). Calorific values of the soft parts of the tellinid bivalve Macoma balthica (L.) as determined by two methods. J. exp. mar Biol. Ecol. 37. 19-30

Booth. J. D. (1977). Common bivalve larvae from New Zealand: Mytilacea. N. Z. J! mar. Freshwat. Res. 11: 407-440

Brody, S. (1945). Bioenergetics and growth. Reinhold, New York

Buccheri, G., Palisano, G. (1976). Nouvi dati sulla distribuzione geografica di Perna (Perna) picta (Born, 1780) e considerazioni sistematiche sulla specie. Conchiglie (Un malac. ital., Milano) 12: 143-156

Fisher, W., Schneider, M., Bauchot, M. L. (1987). Fiches F.A.O d'identification des espèces pour les besoins de la pêche (Revision 1). Méditerranée et Mer Noire. Zone de pêche 37. Volume I. Végétaux et invertébrés. Publication préparée par la F.A.O. et la Commission des Communautés Européennes (Projet GCP/INT/422 EEC) financée conjointement par ces deux organisations. FAO, Rome

Gantes, H. (1967). Aperçu de la zonation de la côte rocheuse marocaine. Bull. Soc. Sci. Nat. Phys. Maroc 47 (3\&4): $317-327$ 
Greenway, J. P. C. (1969a). Survey of mussels (Mollusca: Lamellibranchia) in the Firth of Thames, 1961-67 N. Z. Jl mar. Freshwat. Res. 3: 304-317

Greenway, J. P. C. (1969b). Settlement and growth of a colony of the large green mussel from a pontoon in Tekouma Harbour, Coromandel. N. Z. Marine Department, Fisheries Technical Report 43, p. 1-14

Greenway, J. P. C. (1975). Development of a colony of green mussels, Perna canalicuius, in Coromandel Harbour, 1971-1972. N Z. Ministry of Agriculture and Fisheries, Fisheries Technical Report 141, p. 1-22

Guilcher, A., Joly, F. (1954). Recherches sur la morphologie de la côte occidentale du Maroc. Trav. Inst. Sci. Chérifien Ser. Géol. Géogr. Phys. 2: 1-140

Hickman, R. W., Illingworth, J. (1980). Condition cycle of the green lipped mussel Perna canaliculus in New Zealand. Mar Biol. 60: 27-38

Kennedy, V S. (1977). Reproduction in Mytilus edulis aoteanus and Aulacomya maoriana (Mollusca: Bivalvia) from Taylors Mistake, New Zealand. N. Z. Jl mar. Freshwat. Res. 11 (2): 225-267

Lubet, P. (1973). Exposé synoptique des données biologiques sur la moule Mytilus galloprovincialis (Lamark 1819). Synop. F.A.O. pêches 88: pag. var.

Lubet, P. (1981). Action de la température sur le cycle de reproduction des lamellibranches. Bull. Soc. Zool. Fr $106(3): 283-292$

Lee, S. Y (1986). Growth and reproduction of the green mussel Perna viridis (L.) (Bivalvia: Mytilacea) in contrasting environments in Hong Kong. Asian mar Biol. 3: $111-127$

Lunetta, J. E. (1969). Fisiologia da reproduçâo dos mexilhôes

This article was submitted to the editor
(Mytilus perna - Mollusca Lamellibranchia). Bolm Fac. Filos. Ciênc. Univ. S. Paulo 26: 33-111

Martoja, R., Martoja, M. (1967). Initiation aux techniques de l'histologie animale. Masson et Cie, Paris

Nordsieck, F. (1969). Die Europäischen Meeresmuscheln (Bivalvia). G. Fischer, Stuttgart

Piani, P. (1980). Catalogo dei molluschi conchiferi viventi nel mediterranea. Boll. malcalog. (Un. Malcologica Ital.) 15 $(5-6)$ : $113-222$

Ricker, W. E. (1973). Linear regressions in fishery research. J. Fish. Res. Bd Can. 30: 409-434

Seed, R. (1975). Reproduction in Mytilus (Mollusca: Bivalvia) in European waters. Pubbl. Staz. zool. Napoli, suppl. 39: $317-334$

Seed, R. (1976). Ecology. In: Bayne, B. L. (ed.) Marine mussels, their ecology and physiology. Cambridge University Press, Cambridge, p. 13-65

Siddall, S. E. (1980). A clarification of the genus Perna (Mytilidae). Bull. mar Sci. 30 (4): 858-870

Virabhadra Rao, K., Krishna Kumari, L., Dwivedi, S. N. (1975). Biology of the green mussel, Mytilus viridis. Indian J. mar. Sci. 4 : $189-197$

Walter, C. (1982). Reproduction and growth in the tropical mussel Perna viridis (Bivalvia: Mytilidae). Kalikasan, Philipp. J. Biol. 11 (1): 83-97

Wilson, J. H., Seed, R. (1974). Reproduction in Mytilus edulis L. (Mollusca: Bivalvia) in Carlingford Lough, Northern Ireland. Ir. Fish. Invest. (Ser B) 15: 1-30

Zaouali, J. (1973). Note sur la presence de Perna perna L. (= Mytilus africanus Chemnitz) dans la region de Bizerte (Tunisie). Bull. Inst. Océanogr. Pêche, Salammbô 2 (4): $637-642$

Manuscript first received: October 11, 1988

Revised version accepted: February 14, 1989 